\title{
EFFECT OF ROW SPACING AND FERTIGATION ON YIELD AND ITS COMPONENTS OF COMMON BEAN (Phaseolus vulgaris) UNDER FURROW IRRIGATION SYSTEM.
}

(Received: 28.2.2012)

\author{
By \\ H. H. Hamed and S.M. Ahmed \\ Horticulture Research Institute, Agriculture Research Center, Giza, Egypt.
}

\begin{abstract}
This study aimed to investigate the response of Nebraska (dry seeds bean cv) and Paulista (green pods bean $\mathrm{cv}$ ) to different row spacing and fertigation under surface irrigation system. Mean plant performances were recorded for the characteristics of plant growth, yield and its components as well as chemical compounds of seeds and green pods. The studied treatments were 1) Row-common fertilization, 2) Row-fertigation, 3) Bed-common fertilization-outside ridges, 4) Bed-common fertilization-inside ridges, 5) Bed-fertigation-outside ridges and 6) Bed-fertigation-inside ridges. The results showed that the highest values were recorded by treatment 2 (row-fertigation) for the characteristics of plant height, seed protein content, seed emergence, number of pods per plant, pod length, pod diameter, number of seeds per pod, number of seeds per plant, first, second class and total seed weight per plant; and treatment 5 (bedfertigation-outside ridges) for the characteristics of number of branches per plant, carbohydrate content, third class seed weight per plant, first, second, third class and total seed weight per area unit $\left(\mathrm{g} / \mathrm{m}^{2}\right)$ on Nebraska cv. While, treatment 2 (row-fertigation) recorded the highest values for the characteristics of dry matter per fresh pod, vitamin C content, seed protein content, carbohydrate content, seed emergence, number of pods per plant, green pod weight per plant, number of seeds per pod, number of seeds per plant, seed index (1000 seed weight), first class and total seed weight per plant; and treatment 5 (bedfertigation-outside ridges) recorded the highest values for pod diameter, pod thickness and first class seed weight per area unit $\left(\mathrm{g} / \mathrm{m}^{2}\right)$ on Paulista cv. Farmers may be recommended to apply bed-fertigation treatment both outside and inside ridges to grow common bean of both dry seeds and green pods that provides higher population density (low row spacing) and (fertigation) which ensure high yield with good quality and high exploitation of fertilizers.
\end{abstract}

Key words: fertigation, Phaseolus vulgaris, row spacing, surface irrigation system, yield and its components.

\section{INTRODUCTION}

Common bean (Phaseolus vulgaris) is one of the most produced vegetable crops in Egypt either for local market or exportation. Some of the problems that meet common bean production in Egypt are the high costs of fertilizers while the yield and income of the crop is not meeting the costs, the low exploiting of sowing area unit, seed bedding and row spacing do not take in considering the difference among cultivars and plant developing in the field and the bad way of quantity and quality of applying fertilizers that result in no homogeneity in the distribution and loosing some amount of fertilizers. The yield and its components, either quantity or quality, depends on good agricultural practices. The most important of these practices are soil preparation and fertilization which mean preparing good seed beds and applying the best amounts of fertilization. Preparing the seed beds includes bed spacing while fertilization includes the method and amount of applying. It is very important to get the most benefit and return of the agricultural area by using the most exploitable fertilization amount and area. Also, it is important to condense the sowing area to get more yields with keeping the quality of that yield as well as to get high income by decreasing the sowing costs. Many researchers studied the effect of row spacing and fertigation on yield and its components. Aminifard et al. (2010) found that plant density affected significantly plant growth and yield of pepper, while Goreta et al. (2005) reported that the growth, yield and fruit size of watermelon were 
affected by row spacing and plant density. Fertigation of nutrients with very great dilution in each irrigation increased the fertilizer use efficiency (Solaimalai et al., 2005). Fertigation through surface irrigation means that the fertilizer is delivered by the surface water. The system should be such that the application and distribution is efficient and uniform, with minimal surface runoff at the lower end of the field, and minimal deep percolation below the crop root zone. Fertigation in general, when well-managed, can provide relatively uniform and timely applications of agricultural chemicals based on soil physical and chemical characteristics, and crop requirements. It can reduce soil compaction by limiting the need for tractors in the field. It reduces operator exposure to direct contact with agricultural chemicals, eliminates mechanical crop damage caused by ground sprayers, saves energy, and reduces environmental hazards. On the other hand, reduced yields or even crop failure may result from poor fertilizer distribution, with the consequent loss of income to farmers. In spite of the above advantages, there has been relatively little use of fertigation in surface irrigation. The inherent management problems associated with this irrigation method, particularly with furrows, may be a primary cause. Uniformity, runoff, and deep percolation are the major factors to be controlled in furrow fertigation, whereas poor fertilizer management will often result from low irrigation uniformity. The majority of furrow irrigation systems are operated with high runoff losses, and deep percolation can occur even with high irrigation uniformity, Sabillon and Merkley, 2004. With surface irrigation, the practice of fertigation becomes much more complex because the water is distributed over the field surface. With surface irrigation, the best timing of fertilizer injections into the water at the head (upstream) end of a field is not easily determined. Slight changes in the injection start and end times can dramatically affect the efficiency and uniformity of fertilizer application. The training of farm labor in operational and management procedures such as the timing of application, concentrations and types of chemicals are needed in order to make fertigation through surface methods a widespread tool in modern irrigated agriculture (Sabillon and Merkley, 2004).

The current trial aimed to 1) studying the effect of bed spacing and the way and amounts of fertilization on the yield quality and quantity, 2) studying the effect of plant condensing on yield quality and quantity either dry seed or green pod yield, 3) studying the increasing of fertilization efficiency quantity and quality, 4) comparing the common way of fertilization to fertigation way where it could decrease the sowing costs through decreasing of labor costs and fertilizer costs and finally, 5) studying the possibility of developing a new simple fertigation system which could be more easier, cheaper and adequate to the Egyptian small holder farmers.

\section{MATERIALS AND METHODS}

The current trial was carried out during 2005 and 2006 seasons at Kaha Vegetable Research Farm, Kalubia Governorate. The study aimed to find out the effect of some agricultural practices for improving productivity of common bean (Phaseolus vulgaris). The chemical analysis of the soil (Table 1) was determined by the procedures outlined in Jackson (1967).

The experiment included:

1- Two common bean cultivars, Nebraska as dry seed cultivar and Paulista as green pods cultivar.

2- Two fertilization treatments, fertigation method and the common method (Figures 1 and 2); Nine watering times were provided to the dry seed yield and six watering times to the green pod yield through the whole season. The common treatment per feddan was $150 \mathrm{~kg}$ super phosphate $+15 \mathrm{~kg}$ ammonium sulfate during soil preparation, $100 \mathrm{Kg}$ ammonium sulfate $+50 \mathrm{Kg}$ super phosphate $+50 \mathrm{Kg}$ potassium sulfate at the first watering after sowing date and $100 \mathrm{Kg}$ ammonium sulfate + $50 \mathrm{Kg}$ potassium sulfate at flowering date. The fertigation treatment was $15000 \mathrm{ppm}(\mathrm{N})+$ 5000 ppm $(\mathrm{P})+30000 \mathrm{ppm}(\mathrm{K})+3000 \mathrm{ppm}$ $(\mathrm{Mg})$. This fertilizing formula used to be applied by common bean growers and as well as applying high potassium fertilizer during the season according to the rate of $0.1 \mathrm{~g}$ per liter of irrigating water each time of watering (Solaimalai et al. 2005). Table 2 shows the quantities of fertilizers that were applied to the square meter of area for fertigation and common fertilization methods. The plant density was doubled in the fertigation method comparing to the common method while, the quantities of fertilizers for fertigation method were lower than the common method. The fertilizers applied were the local produced fertilizers.

3- Two ways of seed bedding, $60 \mathrm{~cm}$ width row 
Table (1): Soil chemical analysis of each experimental treatment.

\begin{tabular}{|c|c|c|c|c|c|c|c|c|c|c|c|c|c|c|c|c|c|c|}
\hline \multirow{2}{*}{ 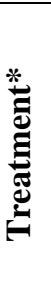 } & \multirow{2}{*}{ 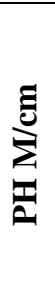 } & \multirow{2}{*}{ 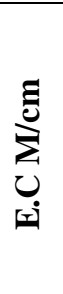 } & \multirow{2}{*}{ రీ } & \multicolumn{4}{|c|}{$\begin{array}{c}\text { Soluble cations } \\
\qquad(\mathrm{M} / \mathrm{L})\end{array}$} & \multicolumn{4}{|c|}{$\begin{array}{c}\text { Soluble anions } \\
\qquad(\mathrm{M} / \mathrm{L})\end{array}$} & \multicolumn{3}{|c|}{$\begin{array}{c}\text { Macro } \\
\text { elements } \\
\text { (ppm) }\end{array}$} & \multicolumn{4}{|c|}{$\begin{array}{c}\text { Micro elements } \\
\text { (ppm) }\end{array}$} \\
\hline & & & & 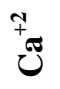 & $\sum^{T+00}$ & ${ }^{+} \bar{Z}$ & $\stackrel{+}{ \pm}$ & ช̃ & $\overbrace{0}^{3}$ & $\bar{\tau}$ & 'ָ & Z & A & $\forall$ & ت & ت & ฟี & $\sum$ \\
\hline $\mathbf{0}$ & 8.4 & $\mathbf{0 . 3 9}$ & 3.6 & 1.0 & 0.65 & 2.19 & 0.48 & - & 1.9 & 0.9 & 1.5 & 38 & 30 & 558 & 4.1 & 2.8 & 1.75 & 2.7 \\
\hline 1 & 7.9 & 0.50 & 7.8 & 0.8 & \begin{tabular}{ll|}
0.4 \\
\end{tabular} & 3.00 & 0.30 & - & 0.4 & 1.0 & $\begin{array}{l}3.1 \\
\end{array}$ & 20 & 25 & $\begin{array}{l}592 \\
\end{array}$ & 2.8 & 1.1 & 0.7 & 1.7 \\
\hline 2 & 7.8 & 0.65 & 6.5 & 1.4 & 0.4 & 3.00 & $\mathbf{0 . 7 0}$ & - & 0.6 & 1.0 & 3.9 & 35 & 20 & 1152 & 3.2 & 1.6 & 0.8 & 2.5 \\
\hline 3 & 7.7 & 0.47 & 3.8 & 0.8 & 0.4 & 2.57 & 0.53 & - & 0.8 & 1.0 & 2.5 & 15 & 20 & 728 & 3.0 & 1.4 & 0.8 & 2.7 \\
\hline 4 & 7.5 & 1.40 & 7.0 & 4.4 & 3 & 4.80 & 1.10 & - & 0.4 & 1.5 & $\mathbf{1 1 . 4}$ & 60 & 31 & 1120 & 2.8 & 1.3 & 0.9 & 3.6 \\
\hline 5 & 7.7 & 0.58 & 5.8 & 1.2 & 0.8 & $\mathbf{3 . 0 0}$ & 0.50 & - & 0.6 & 1.0 & 3.9 & 20 & 36 & 728 & 3.6 & 1.3 & 0.8 & 3.0 \\
\hline 6 & 7.6 & 1.03 & 5.4 & 1.4 & 2.2 & 5.64 & 0.86 & - & 0.6 & 2.0 & 7.5 & 60 & 25 & 776 & 4.2 & 1.4 & 1.0 & 3.5 \\
\hline
\end{tabular}

* $\mathbf{0}=$ soil chemical analysis before adding fertilizers, $1=$ row-common fertilization, $2=$ row-fertigation, $3=$ Bed-common fertilizationoutside ridges, $4=$ Bed-common fertilization-inside ridges, $5=$ Bed-fertigation-outside ridges and $6=$ Bed-fertigation-inside ridges.

Table (2): Comparison between quantities of fertilizers as mineral elements that were applied to one square meter of area for fertigation and common fertilization methods during the whole season.

\begin{tabular}{|c|c|c|}
\hline Mineral element & $\begin{array}{c}\text { Fertigation } \\
\left(48 \text { plants } / \mathrm{m}^{2}\right)\end{array}$ & $\begin{array}{c}\text { Common fertilization } \\
\left(24 \text { plants } / \mathbf{m}^{2}\right)\end{array}$ \\
\hline $\mathbf{N}$ & 7.824 & 11.006 \\
\hline $\mathbf{P}$ & 2.610 & 6.667 \\
\hline $\mathbf{K}$ & 15.660 & 9.762 \\
\hline $\mathrm{Mg}$ & 1.566 & - \\
\hline $\mathrm{Ca}$ & 5.755 & - \\
\hline $\mathbf{F e}$ & 0.176 & - \\
\hline Mn & 0.064 & - \\
\hline $\mathbf{Z n}$ & 0.014 & - \\
\hline $\mathrm{Cu}$ & 0.004 & - \\
\hline B & 0.092 & - \\
\hline Mo & 0.012 & - \\
\hline
\end{tabular}

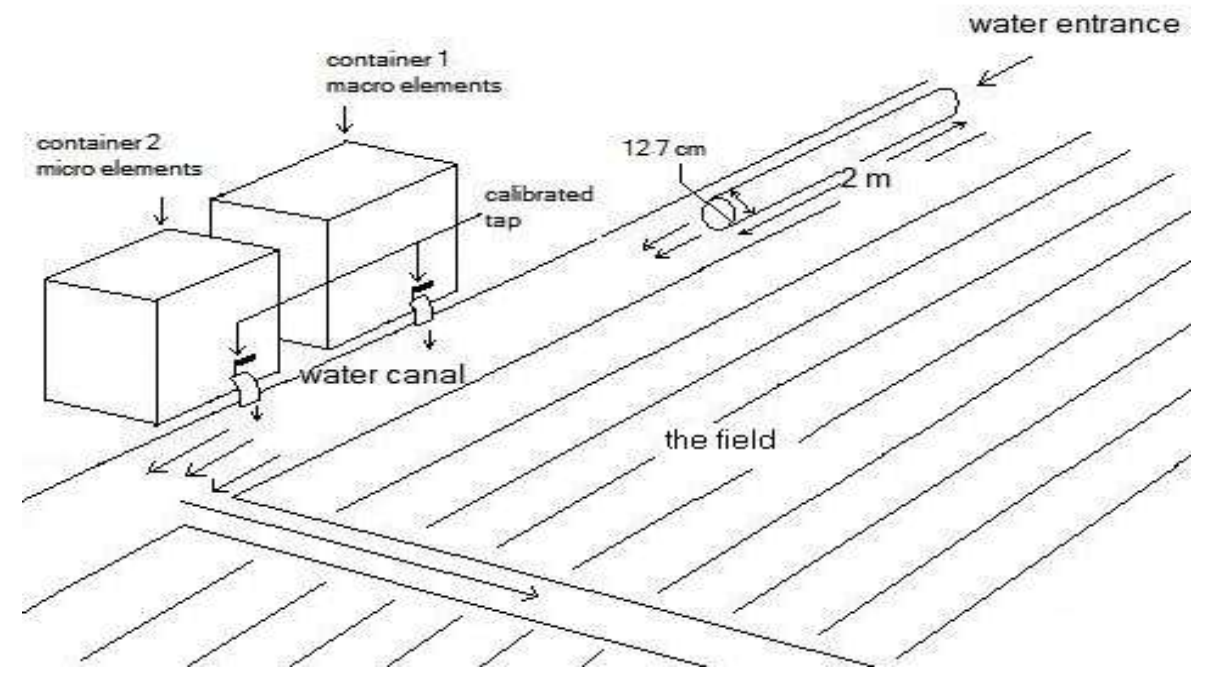

Fig. (1): Field outline, used pipe to calibrate the flow rate and the used containers to apply the fertigation treatment. 

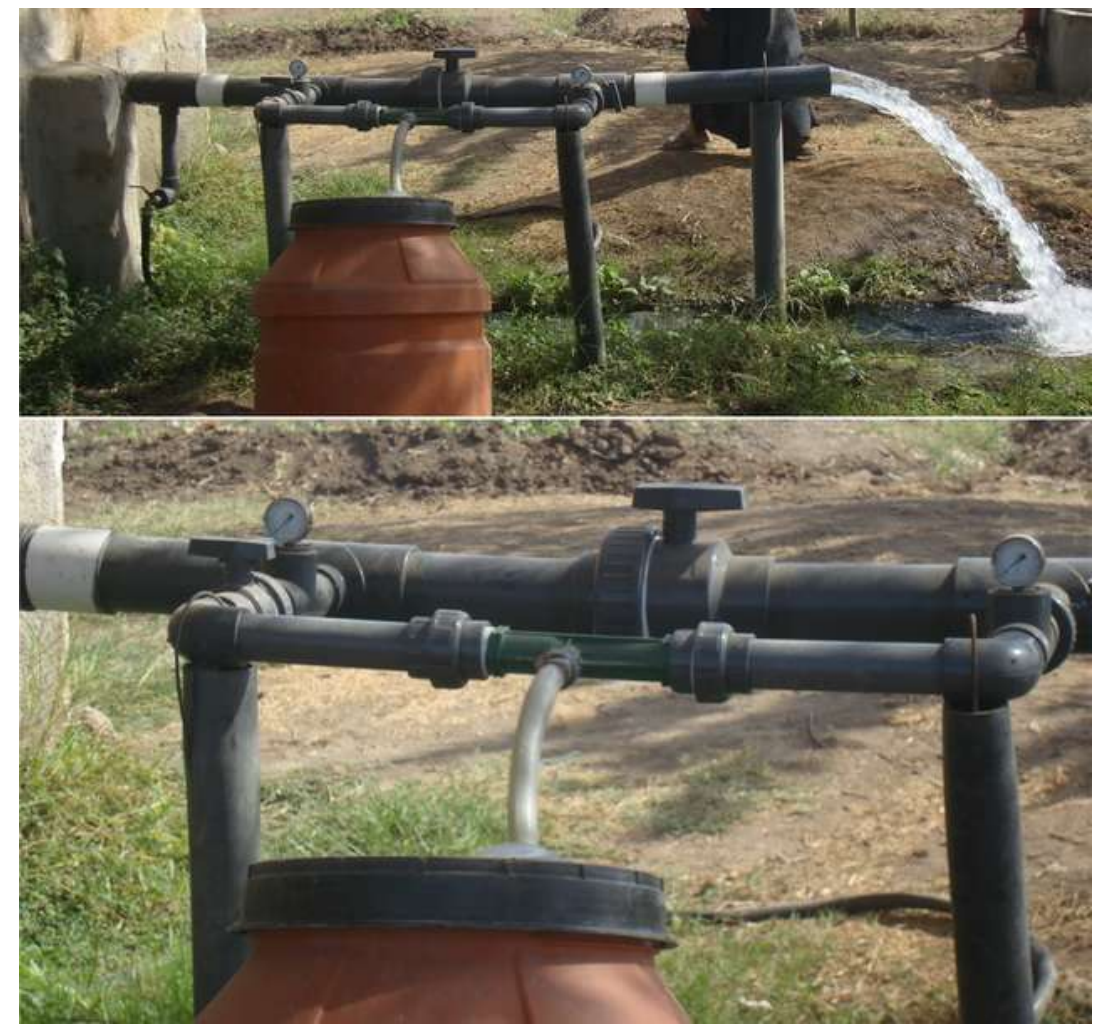

Fig. (2): Practical application of the fertigation method under surface irrigation system in the field.

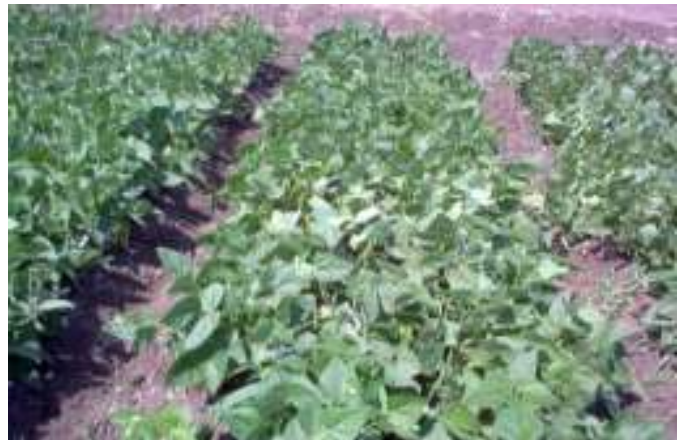

a.

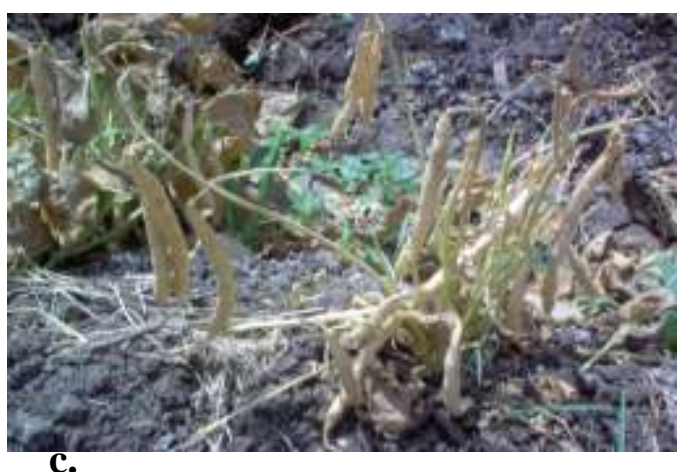

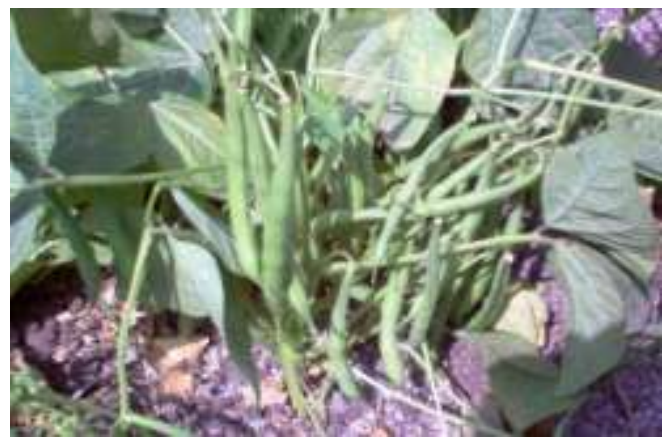

b.

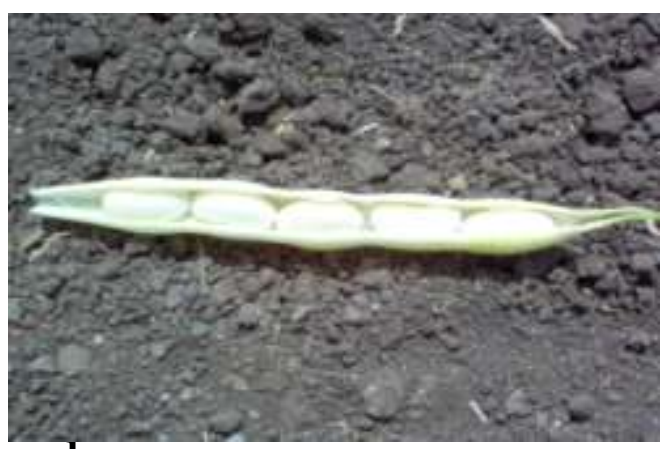

d.

Fig. (3): Showing the bed-fertigation outside and inside treatment (a.), the higher green pod yield (b.), dry seed yield (c.) and seed setting in pods (d.). 
with one ridge and $120 \mathrm{~cm}$ width bed with 4 ridges (two outside and two inside ridges), Figure 3a. To calculate the flow rate (liter/minute) in respect to the fertigation method a PVC pipe of 2 $\mathrm{m}$ length and $12.7 \mathrm{~cm}$ diameter was used and the pipe volume calculated as a volume of cylinder (cylinder volume $=\pi .(\mathrm{r} / 2)^{2}$. L, where $\pi=3.14, \mathrm{r}=$ pipe diameter and $\mathrm{L}=$ pipe length). The water flow speed was calculated as meter per second according to the formula of speed calculation (speed $=$ distance $/$ time) and a plastic table tennis ball was used to calculate the time of flowing through both terminals of the pipe. Calculation of flow rate was used in applying suitable injection rate that provided adequate fertilization injecting at homogenized, speed and frequent rate into irrigating water. A complete randomized block design with three replicates was used. The experimental plot area was 14.4 square meters and consisted of 8 rows of three meters length and 60 $\mathrm{cm}$ width for the common method and 4 beds of three meters length and $120 \mathrm{~cm}$ width for the condensed method, while a $2 \mathrm{~m}$ wide isolating bed was applied between plots to prevent treatments overlap. Seeds were sown at $7 \mathrm{~cm}$ between hills. The plant density was 24 plants $/ \mathrm{m}^{2}$ for the row treatment and 48 plants $/ \mathrm{m}^{2}$ for the bed treatment. Data were recorded for both Nebraska and Paulista cultivars on 5 plants for the characteristics of plant height, number of branches, number of pods/plant, pod length, pod diameter, pod thickness, number of seeds/pod, number of seeds/plant, seed protein content, carbohydrate content, seed emergence, seed index (1000 seed weight), first class seed weight/plant, second class seed weight/plant, third class seed weight/plant, total seed weight/plant, first class seed weight/area unit, second class seed weight/area unit, third class seed weight/area unit, total seed weight/area unit, first class seed weight/area unit, second class seed weight/area unit and third class seed weight/area unit (\%). Data were recorded for Paulista cultivar only for the characteristics of pod fresh weight, dry matter/fresh pod, vitamin C content, green pod weight/plant and green pod weight/area unit. The seeds were sieved and graded by using thieves of 7.33, 6.73, 5.66 and $4.76 \mathrm{~mm}$ for Nebraska seeds and 4.76 and $3.36 \mathrm{~mm}$ for Paulista seeds. Chemical analysis and determination for protein, vitamin $\mathrm{C}$ and carbohydrate content were done according to AOAC (1980). Two ways randomized block analysis (combined analysis) was used to statistically analyze the data according to Minitab personal computer software of Minitab
Inc, 2006. Also, data were tested for least significant differences 5\% (Snedecor and Cochran, 1989) to compare the averages of the determined parameters.

\section{RESULTS AND DISCUSSION \\ 3.1.Effect of row spacing and fertigation on yield and its components of Nebraska \\ The mean squares of response of common} bean (Nebraska cv. dry seed bean) plants to some agricultural practices on vegetative growth and some chemical characteristics are shown in Table 3 . The obtained results showed clearly that there were significant differences for the characteristics of plant height, seed protein content and seed emergence while there was no significant difference for the number of branches per plant. Table 4 shows the mean performances for the characteristics of plant height, number of branches per plant, seed protein content, carbohydrate content and seed emergence. Treatment 2 (rowfertigation) showed the highest measurements for the characteristics of plant height, seed protein content and seed emergence $(33.268 \mathrm{~cm}, 35.546$ $\%$ and $97.000 \%$, respectively), while treatment 5 (bed-fertigation-outside ridges) showed the highest measurements for the characteristics of number of branches per plant and carbohydrate content (6.313 and $14.651 \%$, respectively). These results are in line with those obtained by Mendhe et al., (2002). who mentioned that the plant density of $22.5 \mathrm{~cm}$ recorded highly significantly differences for yield and yield components on Urd bean. In addition, Sekhon et al. (2002) mentioned similar results on Mung bean where higher number of branches, pods per plant and grain yield were obtained under low spacing $(30 \times 10$ and 45 $\mathrm{x} 7 \mathrm{~cm}$ ) and that increased yield.

Table 5 shows the mean squares of characteristics number of pods per plant, pod length, pod diameter, pod thickness, number of seeds per pod, number of seeds per plant and seed index (1000 seed weight). The obtained results showed obviously that there were highly significant differences for the characteristics number of pods per plant and number of seeds per plant. The mean performances of the plants (Table 6) for the previously mentioned characteristics showed the highest traits were for the treatment 1 (row-common fertilization) for pod thickness $(1.056 \mathrm{~cm})$, while treatment 2 (row-fertigation) showed the highest results for the characteristics number of pods per plant (18.298),pod length $(13.692 \mathrm{~cm})$, pod diameter $(1.062 \mathrm{~cm})$, number 
Table (3): Mean squares of response of dry seed bean plants (Nebraska cultivar) to the effect of row spacing and fertigation on yield and its components.

\begin{tabular}{|c|c|c|c|c|c|c|}
\hline Source of variance & DF & $\begin{array}{c}\text { Plant } \\
\text { height }\end{array}$ & $\begin{array}{c}\text { Number } \\
\text { of } \\
\text { branches/ } \\
\text { plant }\end{array}$ & $\begin{array}{l}\text { Seed protein } \\
\text { content }\end{array}$ & $\begin{array}{c}\text { Carbohydrat } \\
\text { e content }\end{array}$ & $\begin{array}{c}\text { Seed } \\
\text { emergence }\end{array}$ \\
\hline Blocks & 2 & 0.126 ns & 0.076 ns & $1.822 \mathrm{~ns}$ & $0.287 \mathrm{~ns}$ & $2.083 \mathrm{~ns}$ \\
\hline Treatments & 5 & $24.016 *$ & 0.899 ns & $171.126 * *$ & $31.905 * *$ & $122.933 * *$ \\
\hline Season & 1 & $2.778 \mathrm{~ns}$ & 0.005 ns & $3.743 *$ & $0.001 \mathrm{~ns}$ & $1.778 \mathrm{~ns}$ \\
\hline Treatments x Season & 5 & $9.232 \mathrm{~ns}$ & 0.279 ns & $2.706 * *$ & $0.168 \mathrm{~ns}$ & 3.044 ns \\
\hline Error & 22 & 7.012 & 0.678 & 0.62 & 0.772 & 1.417 \\
\hline
\end{tabular}

*** significant at 0.05 and 0.01 propability level, respectively. $\mathrm{ns}=$ not significant

Table (4): Means of response of dry seed bean plants (Nebraska cultivar) to the effect of row spacing and fertigation on yield and its components.

\begin{tabular}{|c|c|c|c|c|c|}
\hline Treatments* & $\begin{array}{c}\text { Plant height } \\
(\mathrm{cm})\end{array}$ & $\begin{array}{c}\text { Number of } \\
\text { branches/plant }\end{array}$ & $\begin{array}{c}\text { Seed protein } \\
(\%)\end{array}$ & $\begin{array}{c}\text { Carbohydrate } \\
(\%)\end{array}$ & $\begin{array}{c}\text { Seed emergence } \\
(\%)\end{array}$ \\
\hline 1 & 30.148 ab & 5.897 a & $25.915 \mathrm{~d}$ & $11.020 \mathrm{~b}$ & $94.500 \mathrm{~b}$ \\
\hline 2 & $33.268 \mathrm{a}$ & $6.058 \mathrm{a}$ & $35.546 \mathrm{a}$ & $14.242 \mathrm{a}$ & $97.000 \mathrm{a}$ \\
\hline 3 & $30.853 \mathrm{a}$ & $5.722 \mathrm{a}$ & $25.329 \mathrm{~d}$ & $10.250 \mathrm{~b}$ & 88.333 c \\
\hline 4 & 27.139 b & $5.214 \mathrm{a}$ & $20.437 \mathrm{e}$ & $9.100 \mathrm{c}$ & $85.667 \mathrm{~d}$ \\
\hline 5 & 31.409 a & $6.313 \mathrm{a}$ & $32.082 \mathrm{~b}$ & $14.651 \mathrm{a}$ & $94.833 \mathrm{~b}$ \\
\hline 6 & 30.598 a & $5.554 \mathrm{a}$ & 28.572 c & $10.225 \mathrm{~b}$ & 88.667 c \\
\hline LSD 5\% & 3.171 & 0.986 & 0.943 & 1.052 & 1.425 \\
\hline
\end{tabular}

* 1 = common row - fertilization, 2 = common row - fertigation, 3 =Bed - common fertilization - outside ridges,

4 = Bed - common fertilization - inside ridges, 5 = Bed - fertigation - outside ridges and $6=$ Bed - fertigation - inside ridges Mean values followed by different letter are significantly at the $5 \%$ level.

Table (5): Mean squares of response of dry seed bean plants (Nebraska cultivar) to the effect of row spacing and fertigation on yield and its components.

\begin{tabular}{|c|c|c|c|c|c|c|c|c|}
\hline $\begin{array}{l}\text { Source of } \\
\text { variance }\end{array}$ & DF & $\begin{array}{l}\text { Number of } \\
\text { pods/Plant }\end{array}$ & $\begin{array}{c}\text { Pod } \\
\text { length }\end{array}$ & $\begin{array}{c}\text { Pod } \\
\text { diameter }\end{array}$ & $\begin{array}{c}\text { Pod } \\
\text { thickness }\end{array}$ & $\begin{array}{l}\text { Number of } \\
\text { seeds/Pod }\end{array}$ & $\begin{array}{l}\text { Number of } \\
\text { seeds/Plant }\end{array}$ & $\begin{array}{l}\text { Seed } \\
\text { index }(1000 \\
\text { seed weight })\end{array}$ \\
\hline Blocks & 2 & $4.496 \mathrm{~ns}$ & $0.259 \mathrm{~ns}$ & 0.014 ns & 0.001 ns & $0.987 \mathrm{~ns}$ & $385.111 \mathrm{~ns}$ & 24026.524 ns \\
\hline Treatments & 5 & $74.229 * *$ & $0.620 \mathrm{~ns}$ & $0.010 \mathrm{~ns}$ & 0.017 ns & 0.932 ns & $2171.056 * *$ & $134452.750 \mathrm{~ns}$ \\
\hline Season & 1 & $1.222 \mathrm{~ns}$ & $0.293 \mathrm{~ns}$ & $0.0003 \mathrm{~ns}$ & 0.007 ns & $0.063 \mathrm{~ns}$ & $245.096 \mathrm{~ns}$ & $276772.130 \mathrm{~ns}$ \\
\hline $\begin{array}{l}\text { Treatments } x \\
\text { Season }\end{array}$ & 5 & $7.206 \mathrm{~ns}$ & 0.921 ns & $0.008 \mathrm{~ns}$ & 0.001 ns & $0.546 \mathrm{~ns}$ & $341.258 \mathrm{~ns}$ & $150686.370 \mathrm{~ns}$ \\
\hline Error & 22 & 7.237 & 0.747 & 0.015 & 0.008 & 0.598 & 323.532 & 103063.43 \\
\hline
\end{tabular}

*** significant at 0.05 and 0.01 propability level, respectively. $\mathrm{ns}=$ not significant

Table (6): Means of response of dry seed bean plants (Nebraska cultivar) to the effect of row spacing and fertigation on yield and its components.

\begin{tabular}{|c|c|c|c|c|c|c|c|}
\hline Treatments* & $\begin{array}{l}\text { Number of } \\
\text { pods/Plant }\end{array}$ & $\begin{array}{l}\text { Pod length } \\
\quad(\mathrm{cm})\end{array}$ & $\begin{array}{c}\text { Pod } \\
\text { diameter } \\
(\mathrm{cm}) \\
\end{array}$ & $\begin{array}{c}\text { Pod } \\
\text { thickness } \\
(\mathbf{c m})\end{array}$ & $\begin{array}{c}\text { Number of } \\
\text { seeds/Pod }\end{array}$ & $\begin{array}{l}\text { Number of } \\
\text { seeds/Plant }\end{array}$ & $\begin{array}{l}\text { Seed index } \\
(1000 \text { seed } \\
\text { weight, g) }\end{array}$ \\
\hline 1 & $16.227 \mathrm{a}$ & $13.208 \mathrm{a}$ & 0.937 a & $1.056 \mathrm{a}$ & $4.380 \mathrm{a}$ & $72.011 \mathrm{a}$ & 215.816 a \\
\hline 2 & $18.298 \mathrm{a}$ & $13.692 \mathrm{a}$ & $1.062 \mathrm{a}$ & $0.955 \mathrm{ab}$ & $4.5 \mathrm{a}$ & $82.216 \mathrm{a}$ & $342.241 \mathrm{a}$ \\
\hline 3 & $11.980 \mathrm{~b}$ & $13.057 \mathrm{a}$ & 0.969 a & $0.928 \mathrm{~b}$ & $3.655 \mathrm{a}$ & $43.657 \mathrm{c}$ & $454.948 \mathrm{a}$ \\
\hline 4 & $9.069 \mathrm{~b}$ & $13.146 \mathrm{a}$ & 0.987 a & $0.903 \mathrm{~b}$ & $3.595 \mathrm{a}$ & $33.413 \mathrm{c}$ & 643.742 a \\
\hline 5 & $16.603 \mathrm{a}$ & 13.138 a & 0.979 a & $0.973 \mathrm{ab}$ & $4.107 \mathrm{a}$ & $68.642 \mathrm{ab}$ & 331.078 a \\
\hline 6 & $12.188 \mathrm{~b}$ & $12.690 \mathrm{a}$ & 0.980 a & $0.942 \mathrm{ab}$ & $3.702 \mathrm{a}$ & 47.851 bc & 493.328 a \\
\hline LSD $5 \%$ & 3.221 & 1.035 & 0.145 & 0.106 & 0.926 & 21.537 & 384.392 \\
\hline
\end{tabular}

* 1 = common row - fertilization, 2 = common row - fertigation, 3 =Bed - common fertilization - outside ridges,

4 = Bed - common fertilization - inside ridges, $5=$ Bed - fertigation - outside ridges and $6=$ Bed - fertigation - inside ridges

Mean values followed by different letter are significantly at the $5 \%$ level. 
of seeds per pod (4.5) and number of seeds per plant. (82.216). The highest trait was shown by treatment 4 (bed-common fertilization-inside ridges) for the characteristic seed index (643.742). These results are in line with Basbag et al. (2002) who mentioned that the highest seed yield was obtained from $40 \mathrm{~cm}$ row spacing on Narbon bean (Vicia narbonensis), and Mendhe et al. (2002) who stated higher number of pods per plant from $22.5 \mathrm{~cm}$ row spacing treatment on Urd bean. In addition, Shirtliffe and Johnston (2002) found that increasing plant population did not affect 1000 seed weight (seed index) on dry bean (Phaseolus vulgaris). Also, Atallah et al. (2002) reported significant results on cucumber for the number of fruits per plant under fertigation treatment

Mean squares and plant performances for the characteristics first, second, third class and total seed weight per plant are shown in Tables 7 and 8 . The obtained results showed significant differences of treatments for the characteristics of first class seed weight per plant and total seed weight per plant, while there were no significant differences of seasons for the same previously mentioned characteristics. There was affection of seasons over treatments because of there were significant differences in (treatment $\mathrm{x}$ season) interaction (Table 7). The highest results were for the treatment 2 (row-fertigation) for the characteristics first, second class and total seed weight per plant $(16.939,8.612$ and $26.334 \mathrm{~g}$, respectively) and for the treatment 5 (bedfertigation-outside ridges) for the third class seed weight per plant $(0.808 \mathrm{~g})$. The obtained results are compatible with the data stated by Basbag et al. (2002), Mendhe et al. (2002), Sekhon et al. (2002) and Uday et al. (2002), who mentioned higher seed yield on Narbon bean (Vicia narbonensis) under treatment of $40 \mathrm{~cm}$ row spacing, higher grain yield of Urd bean using 22.5 $\mathrm{cm}$ of spacing with higher plant population, higher grain yield of Mung bean (Vigna radiata) due to planting geometries $30 \times 10$ and $45 \times 7 \mathrm{~cm}$ and higher seed yield of moth bean (Vigna aconitifolia $)$ due to closer spacing $(30 \times 15 \mathrm{~cm})$. These authors mentioned that these data might be due to higher efficiency of photosynthetsis and chlorophyll contents .Also, it could be due to higher carbohydrate and seed protein contents that were clearly noticed on the data of those two treatments 2 (row-fertigation) and 5 (bedfertigation-outside ridges). In addition, Sagheb and Hobbi (2002) found that tomato yield was significantly increased by the fertigation treatments that enhanced and increased the water and nutrient use efficiency.

Mean squares of the characteristics first class and total seed weight per area unit $\left(\mathrm{g} / \mathrm{m}^{2}\right)$ showed highly significant differences (Table 9). Means of plant performances under the different treatments are shown in Table 10. The highest traits were first, second, third class and total seed weight per area unit $(587.568,337.130,38.619$ and 1037.817 $\mathrm{g} / \mathrm{m}^{2}$, respectively) of treatment 5 (bedfertigation-outside ridges), while treatment 3 (bed-common fertilization-outside ridges) showed the highest measurements for the characteristics second and third class seed weight per area unit (40.262 and $4.7 \%$ ). Treatment 6 (bed-fertigation-inside ridges) showed the highest mean for the characteristics first class seed weight per area unit $(68.678 \%)$. The obtained results are in accordance with the data stated by Sekhon et al. (2002), Mendhe et al. (2002) and Shirtliffe and Johnston (2002).

It is clear that treatment 2 (row-fertigation) and 5 (bed-fertigation-outside ridges) showed the highest mean plant performance in most important characteristics, where treatment 2 (rowfertigation) affected the characteristics plant height, seed protein content, seed emergence, number of pods per plant, pod length, pod diameter, number of seeds per pod, number of seeds per plant, first, second class and total seed weight per plant. Treatment 5 (bed-fertigationoutside ridges) affected the characteristics number of branches per plant, carbohydrate content, third class seed weight per plant, first, second, third class and total seed weight per area unit $\left(\mathrm{g} / \mathrm{m}^{2}\right)$.

\subsection{Effect of row spacing and fertigation on yield and its components of Paulista}

The mean squares of response of Paulista plants ( green pods bean cv) showed highly significant differences for the characteristics dry matter per fresh pod, vitamin C content per pod, seed protein content, carbohydrate content and seed emergence(Table 11) under the current studied treatments, but the interaction between treatments and seasons did not show any significance which means there was no effect of seasons and treatments on each other. The mean of plant performances under the six studied treatments are shown in (Table 12). The highest measurements were the treatment 2 (rowfertigation) for the characteristics dry matter per fresh pod $(21.894 \%)$, vitamin C content per pod $(9.490 \mathrm{mg} / 100 \mathrm{~g}$ fresh weight $)$, seed protein content (31.212\%), carbohydrate content (11.908 
Table (7): Mean squares of response of dry seed bean plants (Nebraska cultivar) to the effect of row spacing and fertigation on yield and its components.

\begin{tabular}{|c|c|c|c|c|c|}
\hline Source of variance & DF & $\begin{array}{c}\text { First class } \\
\text { seed } \\
\text { weight/Plant }\end{array}$ & $\begin{array}{c}\text { Second class } \\
\text { seed } \\
\text { weight/Plant }\end{array}$ & $\begin{array}{c}\text { Third class seed } \\
\text { weight/Plant }\end{array}$ & $\begin{array}{c}\text { Total seed } \\
\text { weight/Plant }\end{array}$ \\
\hline Blocks & 2 & $11.360 \mathrm{~ns}$ & $0.494 \mathrm{~ns}$ & $0.374 \mathrm{~ns}$ & $20.042 \mathrm{~ns}$ \\
\hline Treatments & 5 & $45.161 * *$ & $13.910 \mathrm{~ns}$ & 0.020 ns & $105.442 *$ \\
\hline Season & 1 & $0.062 \mathrm{~ns}$ & $0.168 \mathrm{~ns}$ & $0.0004 \mathrm{~ns}$ & $1.711 \mathrm{~ns}$ \\
\hline Treatments x Season & 5 & $37.736 *$ & $15.088 \mathrm{~ns}$ & 0.055 ns & $96.975 *$ \\
\hline Error & 22 & 9.768 & 7.269 & 0.132 & 27.852 \\
\hline
\end{tabular}

*,** significant at 0.05 and 0.01 propability level, respectively. ns = not significant

Table (8): Means of response of dry seed bean plants (Nebraska cultivar) to the effect of row spacing and fertigation on yield and its components.

\begin{tabular}{|c|c|c|c|c|}
\hline Treatments* & $\begin{array}{l}\text { First class seed } \\
\text { weight/Plant (g) }\end{array}$ & $\begin{array}{c}\text { Second class seed } \\
\text { weight/Plant (g) }\end{array}$ & $\begin{array}{c}\text { Third class } \\
\text { seed } \\
\text { weight/Plant } \\
(\mathrm{g}) \\
\end{array}$ & $\begin{array}{c}\text { Total seed } \\
\text { weight/Plant (g) }\end{array}$ \\
\hline 1 & $10.252 \mathrm{~b}$ & $5.379 \mathrm{ab}$ & 0.701 a & $16.332 \mathrm{~b}$ \\
\hline 2 & $16.939 \mathrm{a}$ & 8.612 a & 0.782 a & 26.334 a \\
\hline 3 & $9.542 \mathrm{~b}$ & $6.874 \mathrm{ab}$ & 0.723 a & $17.139 \mathrm{~b}$ \\
\hline 4 & $10.232 \mathrm{~b}$ & $4.989 \mathrm{~b}$ & 0.649 a & $15.870 \mathrm{~b}$ \\
\hline 5 & $12.691 \mathrm{~b}$ & $7.056 \mathrm{ab}$ & 0.808 a & $21.722 \mathrm{ab}$ \\
\hline 6 & $11.109 \mathrm{~b}$ & $4.630 \mathrm{~b}$ & 0.751 a & $16.490 \mathrm{~b}$ \\
\hline LSD $5 \%$ & 3.742 & 3.228 & 0.434 & 6.319 \\
\hline
\end{tabular}

* 1 = common row - fertilization, 2 = common row - fertigation, 3 =Bed - common fertilization - outside ridges, $4=$ Bed - common fertilization - inside ridges, $5=$ Bed - fertigation - outside ridges and $6=$ Bed fertigation - inside ridges

Mean values followed by different letter are significantly at the $5 \%$ level

Table (9): Mean squares of response of dry seed bean plants (Nebraska cultivar) to the effect of row spacing and fertigation on yield and its components.

\begin{tabular}{|c|c|c|c|c|c|c|c|c|}
\hline $\begin{array}{c}\text { Source of } \\
\text { variance }\end{array}$ & DF & $\begin{array}{c}\text { First class } \\
\text { seed } \\
\text { weight/Area } \\
\text { unit }\end{array}$ & $\begin{array}{c}\text { Second class } \\
\text { seed } \\
\text { weight/Area } \\
\text { unit }\end{array}$ & $\begin{array}{c}\text { Third class } \\
\text { seed } \\
\text { weight/Are } \\
\text { a unit }\end{array}$ & $\begin{array}{c}\text { Total seed } \\
\text { weight/Area } \\
\text { unit }\end{array}$ & $\begin{array}{c}\text { First class } \\
\text { seed } \\
\text { weight/Are } \\
\text { a unit }\end{array}$ & $\begin{array}{c}\text { Second } \\
\text { class seed } \\
\text { weight/Are } \\
\text { a unit }\end{array}$ & $\begin{array}{c}\text { Third } \\
\text { class } \\
\text { seed } \\
\text { weight/ } \\
\text { Area } \\
\text { unit }\end{array}$ \\
\hline Blocks & 2 & $15135.001 \mathrm{~ns}$ & $1831.430 \mathrm{~ns}$ & $518.501 \mathrm{~ns}$ & 32569.676 ns & $84.412 \mathrm{~ns}$ & $58.049 \mathrm{~ns}$ & $12.501 *$ \\
\hline Treatments & 5 & $\mathbf{8 5 3 0 3 . 5 1 6} * *$ & 37383.446 ns & $517.025 \mathrm{~ns}$ & $278629.130 * *$ & $139.989 \mathrm{~ns}$ & $130.994 \mathrm{~ns}$ & $2.052 \mathrm{~ns}$ \\
\hline Season & 1 & $9629.423 \mathrm{~ns}$ & $3039.986 \mathrm{~ns}$ & $2.889 \mathrm{~ns}$ & $52654.405 \mathrm{~ns}$ & $8.903 \mathrm{~ns}$ & $13.783 \mathrm{~ns}$ & $0.531 \mathrm{~ns}$ \\
\hline $\begin{array}{c}\text { Treatments } \\
\text { x Season }\end{array}$ & 5 & 44178.466 ns & $31625.800 \mathrm{~ns}$ & $108.139 \mathrm{~ns}$ & $157202.960 *$ & $128.441 \mathrm{~ns}$ & $114.134 \mathrm{~ns}$ & $3.407 \mathrm{~ns}$ \\
\hline Error & 22 & 16812.586 & 15928.443 & 247.234 & 56844.371 & 91.121 & 75.538 & 2.553 \\
\hline
\end{tabular}

*** significant at 0.05 and 0.01 propability level, respectively. $\mathrm{ns}=$ not significant

Table (10): Means of response of dry seed bean plants (Nebraska cultivar) to the effect of row spacing and fertigation on yield and its components.

\begin{tabular}{|c|c|c|c|c|c|c|c|}
\hline Treatments* & $\begin{array}{c}\text { First class } \\
\text { seed } \\
\text { weight/Area } \\
\text { unit }\left(\mathrm{g} / \mathrm{m}^{2}\right)\end{array}$ & $\begin{array}{c}\text { Second } \\
\text { class seed } \\
\text { weight/Area } \\
\text { unit }\left(\mathrm{g} / \mathbf{m}^{2}\right)\end{array}$ & $\begin{array}{c}\text { Third class } \\
\text { seed } \\
\text { weight/Area } \\
\text { unit }\left(\mathrm{g} / \mathrm{m}^{2}\right)\end{array}$ & $\begin{array}{c}\text { Total seed } \\
\text { weight/Area } \\
\text { unit }\left(\mathrm{g} / \mathbf{m}^{2}\right)\end{array}$ & $\begin{array}{c}\text { First class } \\
\text { seed } \\
\text { weight/Area } \\
\text { unit }(\%)\end{array}$ & $\begin{array}{c}\text { Second } \\
\text { class seed } \\
\text { weight/Area } \\
\text { unit }(\%)\end{array}$ & $\begin{array}{c}\text { Third class } \\
\text { seed } \\
\text { weight/Area } \\
\text { unit }(\%)\end{array}$ \\
\hline 1 & $244.908 \mathrm{c}$ & $128.493 \mathrm{~b}$ & $16.740 \mathrm{~b}$ & $390.141 \mathrm{c}$ & $60.578 \mathrm{ab}$ & $35.043 \mathrm{ab}$ & $4.379 \mathrm{a}$ \\
\hline 2 & $404.644 \mathrm{~b}$ & $205.729 \mathrm{ab}$ & $18.690 \mathrm{ab}$ & $629.063 \mathrm{bc}$ & $63.812 \mathrm{ab}$ & $33.172 \mathrm{ab}$ & $3.016 \mathrm{a}$ \\
\hline 3 & $455.894 \mathrm{ab}$ & $328.414 \mathrm{a}$ & $34.553 \mathrm{ab}$ & 818.862 ab & 55.039 b & $40.262 \mathrm{a}$ & $4.700 \mathrm{a}$ \\
\hline 4 & $488.857 \mathrm{ab}$ & $238.351 \mathrm{ab}$ & 31.021 ab & $758.228 \mathrm{ab}$ & $66.802 \mathrm{ab}$ & $28.901 \mathrm{ab}$ & $4.297 \mathrm{a}$ \\
\hline 5 & 587.568 a & 337.130 a & $38.619 a$ & 1037.817 a & $62.723 \mathrm{ab}$ & $33.359 \mathrm{ab}$ & $3.919 \mathrm{a}$ \\
\hline 6 & $530.769 \mathrm{ab}$ & $221.220 \mathrm{ab}$ & $35.869 \mathrm{ab}$ & $787.857 \mathrm{ab}$ & $68.678 \mathrm{a}$ & $27.058 \mathrm{~b}$ & $4.264 \mathrm{a}$ \\
\hline LSD $5 \%$ & 155.253 & 151.115 & 18.827 & 285.473 & 11.43 & 10.406 & 1.913 \\
\hline
\end{tabular}

* 1 = common row - fertilization, 2 = common row - fertigation, 3 =Bed - common fertilization - outside ridges,

4 = Bed - common fertilization - inside ridges, $5=$ Bed - fertigation - outside ridges and $6=$ Bed - fertigation - inside ridges -Mean values followed by different letter are significantly at the $5 \%$ level 
Table (11): Mean squares of response of green pod bean plants (Paulista cultivar) to the effect of row spacing and fertigation on yield and its components.

\begin{tabular}{|c|c|c|c|c|c|c|c|c|}
\hline Source of variance & DF & $\begin{array}{l}\text { Plant } \\
\text { hight }\end{array}$ & $\begin{array}{c}\text { Number } \\
\text { of } \\
\text { branches/ } \\
\text { plant }\end{array}$ & $\begin{array}{c}\text { Dry } \\
\text { matter/ } \\
\text { Fresh pod }\end{array}$ & $\begin{array}{c}\text { Vitamin } \\
\mathrm{C} \\
\text { content }\end{array}$ & $\begin{array}{c}\text { Seed } \\
\text { protien } \\
\text { content }\end{array}$ & $\begin{array}{c}\text { Charpoh } \\
\text { ydrate } \\
\text { content }\end{array}$ & $\begin{array}{c}\text { Seed } \\
\text { emergenc } \\
\mathrm{e}\end{array}$ \\
\hline Blocks & 2 & $4.947 \mathrm{~ns}$ & 0.491 ns & $0.408 \mathrm{~ns}$ & $0.382 \mathrm{~ns}$ & $2.731 *$ & 0.555 ns & 0.333 ns \\
\hline Treatments & 5 & $12.704 \mathrm{~ns}$ & $1.154 \mathrm{~ns}$ & $11.008 * *$ & $6.783 * *$ & $133.131 * *$ & $20.592 * *$ & $76.467 * *$ \\
\hline Season & 1 & 0.790 ns & $0.056 \mathrm{~ns}$ & 0.037 ns & $0.334 \mathrm{~ns}$ & $14.198 * *$ & $0.213 \mathrm{~ns}$ & $1.000 \mathrm{~ns}$ \\
\hline Treatments x S & 5 & $5.372 \mathrm{~ns}$ & $0.322 \mathrm{~ns}$ & $0.114 \mathrm{~ns}$ & $0.375 \mathrm{~ns}$ & $0.943 \mathrm{~ns}$ & $0.200 \mathrm{~ns}$ & $2.067 \mathrm{~ns}$ \\
\hline Error & 22 & 10.191709 & 1.387 & 0.373 & 0.18 & 0.637 & 0.413 & 2.303 \\
\hline
\end{tabular}

*** significant at 0.05 and 0.01 propability level, respectively. $\mathrm{ns}=$ not significant

Table (12): Means of response of green pod bean plants (Paulista cultivar) to the effect of row spacing and fertigation on yield and its components.

\begin{tabular}{|c|c|c|c|c|c|c|c|}
\hline Treatments* & $\begin{array}{l}\text { Plant } \\
\text { hight } \\
(\mathbf{c m})\end{array}$ & $\begin{array}{c}\text { Number } \\
\text { of } \\
\text { branches/ } \\
\text { plant }\end{array}$ & $\begin{array}{c}\text { Dry } \\
\text { matter/Fr } \\
\text { esh pod } \\
(\%)\end{array}$ & $\begin{array}{c}\text { Vitamin } \mathrm{C} \\
\text { content/pod } \\
(\mathrm{mg} / 100 \mathrm{~g} \\
\text { fresh weight })\end{array}$ & $\begin{array}{c}\text { Seed } \\
\text { protien } \\
(\%)\end{array}$ & $\begin{array}{c}\text { Charpohydrate } \\
(\%)\end{array}$ & $\begin{array}{c}\text { Seed } \\
\text { emergence } \\
(\%)\end{array}$ \\
\hline 1 & 27.167 a & $6.583 \mathrm{a}$ & $18.146 \mathrm{~d}$ & $7.197 \mathrm{c}$ & $23.748 \mathrm{~d}$ & $9.0198 \mathrm{~b}$ & $94.833 \mathrm{~b}$ \\
\hline 2 & 30.806 a & $6.819 \mathrm{a}$ & 21.894 a & $9.490 \mathrm{a}$ & $31.212 \mathrm{a}$ & 11.908 a & $97.000 \mathrm{a}$ \\
\hline 3 & 29.917 a & $6.500 \mathrm{a}$ & $18.818 \mathrm{~cd}$ & $8.900 \mathrm{~b}$ & 21.996 e & 8.250 bc & $90.833 \mathrm{c}$ \\
\hline 4 & 29.861 a & $6.583 \mathrm{a}$ & $18.687 \mathrm{~cd}$ & $7.348 \mathrm{c}$ & $18.937 \mathrm{f}$ & $7.600 \mathrm{c}$ & $87.833 \mathrm{~d}$ \\
\hline 5 & 30.778 a & $7.417 \mathrm{a}$ & 20.102 b & $8.890 \mathrm{~b}$ & 29.915 b & 11.818 a & $94.833 \mathrm{~b}$ \\
\hline 6 & 31.139 a & $7.472 \mathrm{a}$ & $19.141 \mathrm{c}$ & $7.057 \mathrm{c}$ & 26.239 c & $8.725 \mathrm{~b}$ & 89.667 c \\
\hline LSD 5\% & 3.822 & 1.41 & 0.731 & 0.507 & 0.956 & 0.769 & 1.817 \\
\hline
\end{tabular}

* 1 = common row - fertilization, 2 = common row - fertigation, 3 =Bed - common fertilization - outside ridges,

4 = Bed - common fertilization - inside ridges, 5 = Bed - fertigation - outside ridges and 6 = Bed - fertigation - inside ridges -

Mean values followed by different letter are significantly at the $5 \%$ level

$\%)$ and seed emergence (97.000\%). While the highest measurements of the characteristics plant height $(31.139 \mathrm{~cm})$ and number of branches per plant (7.472) were recorded by the treatment 6 (bed-fertigation-inside ridges). These results are compatible with the data recorded by Srivastava and Srivastava (2003) who stated the highest plant height records on rice bean (Vigna umbellata). Mendhe et al. (2002) stated higher number of branches per plant on Urd bean and Ramakrishna et al. (2002) mentioned significant differences and higher records of dry matter on French bean (Phaseolus vulgaris). Atallah et al. (2002) on cucumber, Janat and Somi (2002) on cotton and Martinez et al. (1991) on sweet corn stated that fertigation improved water and nitrogen use efficiency and resulted in significant increase in dry matter.

High significant differences were showed by the characteristics number of pods per plant, green pod weight per plant, number of seeds per plant and seed index (1000 seed weight) as affected by the different treatments (Table 13). The mean plant performance for the characteristics number of pods per plant, pod length, pod diameter, pod thickness, average pod fresh weight, green pod weight per area unit, number of seeds per pod, number of seeds per plant and seed index showed in Table14. The treatment 2 (row -fertigation) recorded the highest means for the characteristics number of pods per plant (31.194), green pod weight per plant $(109.525 \mathrm{~g})$, number of seeds per pod (7.000), number of seeds per plant (216.944) and seed index (1000 seed weight, 128.847 g).Treatment 3 (bed - common fertilization outside ridges) showed the highest mean for the character green pod weight per area unit $\left(3812.652 \mathrm{~g} / \mathrm{m}^{2}\right)$. The treatment 5 (bed -fertigation - outside ridges) for the characteristics pod diameter $(0.746 \mathrm{~cm})$ and pod thickness $(0.695$ $\mathrm{cm}$ ). The treatment 6 (bed - fertigation - inside ridges) recorded the highest means for the characteristics pod length $(15.283 \mathrm{~cm})$ and average pod fresh weight $(4.076 \mathrm{~g})$. The recorded data are in line with those mentioned by Mendhe et al. (2002) who stated higher number of pods per plant under $22.5 \mathrm{~cm}$ row spacing on Urd bean. Sarkar et al. (2004) mentioned the highest number of pods per plant, highest pod length, highest 1000 seed weight (seed index) under spacing of $30 \times 10$ and $20 \times 20 \mathrm{~cm}$ on mung bean. Srivastava and Srivastava (2003) stated the highest records for number of pods per plant, number of seeds per pod and 1000 grain weight (seed index) under 45 
Table (13): Mean squares of response of green pod bean plants (Paulista cultivar) to the effect of row spacing and fertigation on yield and its components.

\begin{tabular}{|c|c|c|c|c|c|c|c|c|c|c|c|}
\hline $\begin{array}{l}\text { Source of } \\
\text { variance }\end{array}$ & DF & $\begin{array}{l}\text { Number of } \\
\text { pods/Plant }\end{array}$ & $\begin{array}{c}\text { Pod } \\
\text { length }\end{array}$ & $\begin{array}{c}\text { Pod } \\
\text { diameter }\end{array}$ & $\begin{array}{c}\text { Pod } \\
\text { thickness }\end{array}$ & $\begin{array}{l}\text { Avarege } \\
\text { pod fresh } \\
\text { weight }\end{array}$ & $\begin{array}{c}\text { green pod } \\
\text { weight/Plant }\end{array}$ & $\begin{array}{c}\text { green pod } \\
\text { weight/area } \\
\text { unit }\end{array}$ & $\begin{array}{l}\text { Number of } \\
\text { seeds/Pod }\end{array}$ & $\begin{array}{l}\text { Number of } \\
\text { seeds/Plant }\end{array}$ & Seed index \\
\hline Blocks & 2 & $53.803 \mathrm{~ns}$ & $0.259 \mathrm{~ns}$ & $0.003 \mathrm{~ns}$ & $0.004 \mathrm{~ns}$ & $0.188 \mathrm{~ns}$ & $1392.125 \mathrm{~ns}$ & $2552886.300 \mathrm{~ns}$ & $1.444 \mathrm{~ns}$ & $1493.796 \mathrm{~ns}$ & $78.784 \mathrm{~ns}$ \\
\hline Treatments & 5 & $199.406 *$ & $0.828 \mathrm{~ns}$ & $0.002 \mathrm{~ns}$ & $0.001 \mathrm{~ns}$ & $0.396 \mathrm{~ns}$ & $1952.813 \mathrm{~ns}$ & $2564684.400 *$ & $0.807 \mathrm{~ns}$ & $10904.989 * *$ & $1990.058 * *$ \\
\hline Season & 1 & $111.713 \mathrm{~ns}$ & $0.250 \mathrm{~ns}$ & $0.001 \mathrm{~ns}$ & $0.00004 \mathrm{~ns}$ & $0.643 \mathrm{~ns}$ & $526.153 \mathrm{~ns}$ & $584089.400 \mathrm{~ns}$ & $0.174 \mathrm{~ns}$ & $3490.840 \mathrm{~ns}$ & $59.995 \mathrm{~ns}$ \\
\hline $\begin{array}{l}\text { Treatments } x \\
\text { Season }\end{array}$ & 5 & $18.478 \mathrm{~ns}$ & $0.592 \mathrm{~ns}$ & $0.0005 \mathrm{~ns}$ & $0.0002 \mathrm{~ns}$ & $0.489 \mathrm{~ns}$ & $421.561 \mathrm{~ns}$ & $562164.180 \mathrm{~ns}$ & $0.240 \mathrm{~ns}$ & $1445.872 \mathrm{~ns}$ & $397.389 \mathrm{~ns}$ \\
\hline Error & 22 & 55.477 & 0.559 & 0.001 & 0.001 & 0.226 & 811.255 & 947722.01 & 0.634 & 2478.597 & 393.846 \\
\hline
\end{tabular}

*,** significant at 0.05 and 0.01 propability level, respectively. $\mathrm{ns}=$ not significant

Table (14): Means of response of green pod bean plants (Paulista cultivar) to the effect of row spacing and fertigation on yield and its components.

\begin{tabular}{|c|c|c|c|c|c|c|c|c|c|c|}
\hline Treatments* & $\begin{array}{l}\text { Number of } \\
\text { pods/Plant }\end{array}$ & $\begin{array}{c}\text { Pod } \\
\text { length } \\
(\mathrm{cm})\end{array}$ & $\begin{array}{c}\text { Pod } \\
\text { diameter } \\
(\mathbf{c m})\end{array}$ & $\begin{array}{l}\text { Pod } \\
\text { thickness } \\
\quad(\mathbf{c m})\end{array}$ & $\begin{array}{l}\text { Avarege } \\
\text { pod fresh } \\
\text { weight }(g)\end{array}$ & $\begin{array}{c}\text { green pod } \\
\text { weight/Plant } \\
\text { (g) }\end{array}$ & $\begin{array}{c}\text { green pod } \\
\text { weight/area } \\
\text { unit }\left(g / \mathbf{m}^{2}\right)\end{array}$ & $\begin{array}{l}\text { Number of } \\
\text { seeds/Pod }\end{array}$ & $\begin{array}{l}\text { Number of } \\
\text { seeds/Plant }\end{array}$ & $\begin{array}{c}\text { Seed index } \\
(1000 \text { seed } \\
\text { weight, } g)\end{array}$ \\
\hline 1 & $22.319 \mathrm{ab}$ & $14.658 \mathrm{ab}$ & $0.736 \mathrm{a}$ & $0.672 \mathrm{a}$ & $3.610 \mathrm{a}$ & $80.103 a b$ & $1842.358 \mathrm{c}$ & $6.417 \mathrm{a}$ & $143.701 \mathrm{~b}$ & $105.134 \mathrm{ab}$ \\
\hline 2 & $31.194 \mathrm{a}$ & $14.275 \mathrm{~b}$ & $0.739 \mathrm{a}$ & $0.689 \mathrm{a}$ & $3.456 \mathrm{a}$ & $109.525 \mathrm{a}$ & $2519.072 \mathrm{bc}$ & $7.000 \mathrm{a}$ & $216.944 \mathrm{a}$ & $128.847 \mathrm{a}$ \\
\hline 3 & $23.139 \mathrm{ab}$ & $14.317 \mathrm{ab}$ & $0.724 \mathrm{a}$ & $0.676 \mathrm{a}$ & $3.668 \mathrm{a}$ & $82.884 a b$ & $3812.652 \mathrm{a}$ & $6.083 \mathrm{a}$ & $140.917 \mathrm{~b}$ & $93.558 \mathrm{bc}$ \\
\hline 4 & $15.417 \mathrm{~b}$ & $14.608 \mathrm{ab}$ & $0.697 \mathrm{a}$ & $0.653 \mathrm{a}$ & $3.969 \mathrm{a}$ & $61.547 \mathrm{~b}$ & $2831.145 \mathrm{abc}$ & $6.083 \mathrm{a}$ & $94.563 \mathrm{~b}$ & $75.693 \mathrm{c}$ \\
\hline 5 & $17.972 \mathrm{~b}$ & $14.842 \mathrm{ab}$ & $0.746 \mathrm{a}$ & $0.695 \mathrm{a}$ & $3.480 \mathrm{a}$ & $62.420 \mathrm{~b}$ & $2871.337 \mathrm{abc}$ & $6.750 \mathrm{a}$ & $121.653 \mathrm{~b}$ & $109.273 \mathrm{ab}$ \\
\hline 6 & $0.028 \mathrm{~b}$ & $15.283 \mathrm{a}$ & $0.712 \mathrm{a}$ & $0.670 \mathrm{a}$ & $4.076 \mathrm{a}$ & $68.330 \mathrm{~b}$ & $3143.163 \mathrm{ab}$ & $6.583 \mathrm{a}$ & $112.292 \mathrm{~b}$ & $90.866 \mathrm{bc}$ \\
\hline LSD 5\% & 8.918 & 0.896 & 0.045 & 0.043 & 0.57 & 34.104 & 1165.634 & 0.953 & 59.611 & 23.762 \\
\hline
\end{tabular}

* 1 = Common row - fertilization, 2 = Common row - fertigation, 3 =Bed - Common fertilization - outside ridges, 4 = Bed - Common fertilization - inside ridges, 5 = Bed - fertigation - outside ridges and $6=$ Bed - fertigation - inside ridges. 
Table (15): Mean squares of response of green pod bean plants (Paulista cultivar) to the effect of row spacing and fertigation on yield and its components.

\begin{tabular}{|c|c|c|c|c|c|c|c|c|c|}
\hline $\begin{array}{c}\text { Source of } \\
\text { variance }\end{array}$ & DF & $\begin{array}{c}\text { First class } \\
\text { seed } \\
\text { weight/Plant }\end{array}$ & $\begin{array}{l}\text { Second class } \\
\text { seed } \\
\text { weight/Plant }\end{array}$ & $\begin{array}{c}\text { Total seed } \\
\text { weight/Plant }\end{array}$ & $\begin{array}{c}\text { First class } \\
\text { seed } \\
\text { weight/Area } \\
\text { unit }\end{array}$ & $\begin{array}{c}\text { Second class } \\
\text { seed } \\
\text { weight/Area } \\
\text { unit }\end{array}$ & $\begin{array}{c}\text { Total seed } \\
\text { weight/Area } \\
\text { unit }\end{array}$ & $\begin{array}{c}\text { First class } \\
\text { seed } \\
\text { weight/Area } \\
\text { unit }\end{array}$ & $\begin{array}{c}\text { Second } \\
\text { class seed } \\
\text { weight/Area } \\
\text { unit }\end{array}$ \\
\hline Blocks & 2 & $6.815 \mathrm{~ns}$ & $5.444 \mathrm{~ns}$ & $7.631 \mathrm{~ns}$ & $10531.563 \mathrm{~ns}$ & $12976.065 \mathrm{~ns}$ & $\begin{array}{c}13246.841 \\
\text { ns }\end{array}$ & $107.317 \mathrm{~ns}$ & $107.317 \mathrm{~ns}$ \\
\hline Treatments & 5 & $20.568 * *$ & $50.933 * *$ & $58.720 \mathrm{~ns}$ & $63498.757 * *$ & $\begin{array}{c}128535.880 \\
* *\end{array}$ & $\begin{array}{c}203574.350 \\
*\end{array}$ & $832.301 * *$ & $832.301 * *$ \\
\hline Season & 1 & $2.498 \mathrm{~ns}$ & $0.0009 \mathrm{~ns}$ & $2.591 \mathrm{~ns}$ & $765.180 \mathrm{~ns}$ & $4210.004 \mathrm{~ns}$ & $1385.527 \mathrm{~ns}$ & $38.340 \mathrm{~ns}$ & $38.340 \mathrm{~ns}$ \\
\hline $\begin{array}{l}\text { Treatments } x \\
\text { Season }\end{array}$ & 5 & $4.017 \mathrm{~ns}$ & $10.752 \mathrm{~ns}$ & $25.975 \mathrm{~ns}$ & $4758.331 \mathrm{~ns}$ & $13667.201 \mathrm{~ns}$ & $\begin{array}{c}30048.637 \\
\text { ns }\end{array}$ & $81.724 \mathrm{~ns}$ & $81.724 \mathrm{~ns}$ \\
\hline Error & 22 & 4.128 & 12.597 & 28.192 & 8145.355 & 22802.478 & 53319.802 & 77.367 & 77.367 \\
\hline
\end{tabular}

*,** significant at 0.05 and 0.01 propability level, respectively. $\mathrm{ns}=$ not significant

Table (16): Means of response of green pod bean plants (Paulista cultivar) to the effect of row spacing and fertigation on yield and its components.

\begin{tabular}{|c|c|c|c|c|c|c|c|c|}
\hline Treatments* & $\begin{array}{c}\text { First class } \\
\text { seed } \\
\text { weight/Plant } \\
\text { (g) }\end{array}$ & $\begin{array}{l}\text { Second class } \\
\text { seed } \\
\text { weight/Plant } \\
\text { (g) }\end{array}$ & $\begin{array}{c}\text { Total seed } \\
\text { weight/Plant } \\
\text { (g) }\end{array}$ & $\begin{array}{c}\text { First class } \\
\text { seed } \\
\text { weight/Area } \\
\text { unit }\left(\mathrm{g} / \mathrm{m}^{2}\right)\end{array}$ & $\begin{array}{c}\text { Second class } \\
\text { seed } \\
\text { weight/Area } \\
\text { unit }\left(\mathrm{g} / \mathbf{m}^{2}\right)\end{array}$ & $\begin{array}{c}\text { Total seed } \\
\text { weight/Area } \\
\text { unit }\left(\mathrm{g} / \mathrm{m}^{2}\right)\end{array}$ & $\begin{array}{c}\text { First class } \\
\text { seed } \\
\text { weight/Area } \\
\text { unit }(\%)\end{array}$ & $\begin{array}{c}\text { Second class } \\
\text { seed } \\
\text { weight/Area } \\
\text { unit }(\%)\end{array}$ \\
\hline 1 & $9.135 \mathrm{ab}$ & $5.890 \mathrm{~b}$ & $15.0244 \mathrm{~b}$ & $218.211 \mathrm{c}$ & $140.692 \mathrm{~b}$ & $358.903 \mathrm{c}$ & $62.394 \mathrm{abc}$ & $37.606 \mathrm{bcd}$ \\
\hline 2 & $11.323 \mathrm{a}$ & $10.778 \mathrm{a}$ & $22.101 \mathrm{a}$ & $270.474 \mathrm{bc}$ & $257.471 \mathrm{~b}$ & $527.944 \mathrm{bc}$ & $52.082 \mathrm{c}$ & $47.918 \mathrm{~b}$ \\
\hline 3 & $9.639 \mathrm{ab}$ & $5.772 \mathrm{~b}$ & $15.411 \mathrm{ab}$ & $460.501 \mathrm{a}$ & $275.771 \mathrm{~b}$ & $736.273 \mathrm{ab}$ & $66.912 \mathrm{a}$ & $33.088 \mathrm{~d}$ \\
\hline 4 & $6.218 c$ & $12.160 \mathrm{a}$ & $18.378 \mathrm{ab}$ & $297.096 \mathrm{bc}$ & $580.958 \mathrm{a}$ & $878.054 \mathrm{a}$ & $34.641 \mathrm{~d}$ & $65.359 \mathrm{a}$ \\
\hline 5 & $9.839 \mathrm{ab}$ & $5.897 \mathrm{~b}$ & $15.736 \mathrm{ab}$ & $470.081 \mathrm{a}$ & $281.748 \mathrm{~b}$ & $751.828 \mathrm{ab}$ & $63.827 \mathrm{ab}$ & $36.173 \mathrm{~cd}$ \\
\hline 6 & $7.288 \mathrm{bc}$ & $6.012 \mathrm{~b}$ & $13.300 \mathrm{~b}$ & $348.211 \mathrm{~b}$ & $287.228 \mathrm{~b}$ & $635.438 \mathrm{abc}$ & $54.977 \mathrm{bc}$ & $45.023 \mathrm{bc}$ \\
\hline LSD $5 \%$ & 2.433 & 4.25 & 6.357 & 108.063 & 180.806 & 276.481 & 10.532 & 10.532 \\
\hline
\end{tabular}

* 1 = Common row - fertilization, 2 = Common row - fertigation, 3 =Bed - Common fertilization - outside ridges, 4 = Bed - Common fertilization - inside ridges, 5 = Bed - fertigation - outside ridges and $6=$ Bed - fertigation - inside ridges . 
$\mathrm{x} 10 \mathrm{~cm}$ row spacing on rice bean (Vigna umbellata). In addition, Atallah et al. (2002) mentioned significantly increase in number of fruits per plant of cucumber under fertigation treatment. Table 15 shows the mean squares for the characteristics first, second class and total seed weight per plant, area unit $\left(\mathrm{g} / \mathrm{m}^{2}\right)$ and area unit $(\%)$. Data showed clearly that there were high significant differences for all characteristics except for total seed weight per plant that showed no significant difference. The mean plant performances for the previously mentioned characteristics under the six studied treatments are shown in (Table 16). The highest means were shown by treatment 2 (row-fertigation) for the characteristics first class and total seed weight per plant (11.323 and $22.101 \mathrm{~g}$ ), treatment 3 (bedcommon fertilization-outside ridges) for the characteristic first class seed weight per area unit (66.912\%),treatment4 (bed-common fertilizationinside ridges) for the characteristics second class seed weight per plant $(12.160 \mathrm{~g})$, second class and total seed weight per area unit (580.958 and $878.054 \mathrm{~g} / \mathrm{m}^{2}$ ) and second class seed weight per area unit $(65.359 \%)$ and treatment 5 (bedfertigation-outside ridges) for the characteristic first class seed weight per area unit (470.081 $\mathrm{g} / \mathrm{m}^{2}$ ). The results are compatible with the data obtained by Srivastava and Srivastava (2003) who worked on rice bean (Vigna umbellata) and found the highest grain yield per area unit under $45 \mathrm{x} 10$ and $30 \times 10 \mathrm{~cm}$ row spacing. Also, in accordance to Zuraiqi et al. (2002) tomato responded significantly to the low $\mathrm{N}$ rates applied by fertigation and produced an acceptable yield with a high efficiency of fertilizer use. It is clear that treatment 2 (row-fertigation) and 5 (bedfertigation-outside ridges) showed the highest mean plant performance in most of the characteristics, where treatment 2 (rowfertigation) affected the characteristics dry matter per fresh pod, vitamin $\mathrm{C}$ content, seed protein content, carbohydrate content, seed emergence, number of pods per plant, green pod weight per plant, number of seeds per pod, number of seeds per plant, seed index (1000 seed weight), first class and total seed weight per plant. Treatment 5 (bed-fertigation-outside ridges) affected the characteristics pod diameter, pod thickness and first class seed weight per area unit $\left(\mathrm{g} / \mathrm{m}^{2}\right)$.

Dividing the treatments 5 and 6 to outside and inside ridges was to test and prove that there was no difference between both outside and inside ridges in quality and quantity. There was no affection of the ridge location on plant performances. The same was recorded for both treatment 3 and 4 . However, It is clear that treatment 5 and 6 were almost the same as well as treatment 3 and 4 .

In addition, since treatments 2 (rowfertigation) and 5 (bed-fertigation-outside ridges) showed the highest values and results, practically treatment 5 (bed-fertigation-outside ridges) was better than treatment 2 (row-fertigation) where treatment 5 (bed-fertigation-outside ridges) and 6 (bed-fertigation-inside ridges) applicably the same.

The results proved the availability of doubling the used area unit and getting higher yield comparing to the common method in growing common beans. It is concluded that farmers are recommended to apply bed-fertigation treatment both outside and inside ridges to grow common bean (Phaseolus vulgaris) of both dry seeds and green pods that provides high population density (low row spacing) and (fertigation) ensure high yield with good quality and higher exploitation of fertilizers.

\section{REFERENCES}

Aminifard M. H., Aroiee H., Karimpour S. and Nemati H. (2010). Growth and yield characteristics of paprika pepper (Capsicum annum L.) in response to plant density. Asian Journal of Plant Sciences 9(5): 276 - 280.

A.O.A.C. (1980). Official methods of analysis, $12^{\text {th }}$ Ed. Association of official analysis chemicals: Washington D.C., U.S.A.

Atallah T., Darwish T. and ElMoujbber M. (2002). Modality of fertigation of protected cucumber and nitrogen use efficiency under field conditions. Results of a technical cooperation project on water balance and fertigation for crop improvement in West Asia. International Atomic Energy Agency (IAEA), Vienna, Austria, pp. 41 - 48.

Basbag M., Doran I. and Samanci B. (2002). Effect of row spacing and phosphorus on seed yield components of narbon bean (Vicia narbonensis). Indian Journal of Agricultural Science, 72(8): 491 - 492.

Goreta S., Perica S., Dumicic G., Bucan L. and Zanic K. (2005). Growth and yield of watermelon on polyethylene mulch with different spacing and nitrogen rates. Hortscience 40(2): 366 - 369.

Jackson M. L. (1967). Soil chemical analysis. Prentice-Hall of India Private Limited - New 
Delhi, pp. 111-204.

Janat M. and Somi G. (2002). Comparative study of nitrogen fertilizer use efficiency of cotton grown under convetional and fertigation practices using ${ }^{15} \mathrm{~N}$ methodology. Results of a technical co-operation project on water balance and fertigation for crop improvement in West Asia. International Atomic Energy Agency (IAEA), Vienna, Austria, pp. 85 - 98.

Martinez Hernandez J. J., Bar-Yosef B. and Kafkafi U. (1991). Effect of surface and subsurface drip fertigation on sweet corn rooting, uptake, dry matter production and yield. Irrig. Sci., 12: 153 - 159.

Mendhe S. N., Chaudhary C. S., Khadse V. A., Sawaji B. V. and Jibhakate B. M. (2002). Response of Urd bean to sowing dates and spacing. Journal of Soils and Crops, 12(2): 254 $-257$.

Minitab Inc. (2006). Minitab software, version 15.1.00.

Ramakrishna K., Krishnappa K. S. and Umamaheswarappa P. (2002). Dry matter production, nutrient accumulation and uptake of primary nutrients in French bean (Phaseolus vulgaris) as affected by genotypes, spacing and fertilizer levels. South Indian Horticulture, 50(1-3): 105 - 112.

Sabillon G. N. and Merkley G. P. (2004). Fertigation guidelines for furrow irrigation. Spanish Journal of Agricultural Research, 2(4): $576-587$.

Sagheb, N. and Hobbi M. S. (2002). Field evaluation of urea fertilizer and water use efficiency by tomato under trickle fertigation and furrow irrigation. Results of a technical cooperation project on water balance and fertigation for crop improvement in West Asia. International Atomic Energy Agency (IAEA), Vienna, Austria, pp. 3 - 13.
Sarkar M. A. R., Kabir M. H., Mahfuza Begum and Salam M. A. (2004). Yield performance of mung bean as affected by planting date, variety and plant density. Journal of Agronomy, 3(1): $18-24$.

Sekhon H. S., Guriqabal Singh, Brar J. S. and Singh G. (2002). Effect of population density and planting geometry on the growth and yield of Mung Bean (Vigna radiata) genotypes. Environment and Ecology, 20(4): 897 - 901.

Shirtliffe S. J. and Johnston A. M. (2002). Yield density relations and optimum plant populations in two cultivars of solid seeded dry bean (Phaseolus vulgaris). Canadian Journal of Plant Science, 82(3): 521 - 529.

Snedecor, G. W. and Cochran, W. G. (1989). Statistical Methods. Eighth Edition, Iowa State University Press.

Solaimalai, A., Baskar M., Sadasakthi A. and Subburamu K. (2005). Fertigation in high value crops. Agric. Rev., 26(1): 1 - 13.

Srivastava G. P. and Srivastava V. C. (2003). Effect of row spacing on yield of rice bean (Vigna umbellata) varieties. Journal of Research, Birsa Agricultural University, 15(1): 95 - 96.

Uday Burman, Garg B. K., Kathju S. and Burman U. (2002). Effect of spacing on seed yield and physiological traits in moth bean (Vicia aconitifolia). Indian Journal of Agricultural Sciences, 72(2): 76 - 79.

Zuraiqi, S., Qawasmi W., Deek I. and Mohamed M. J. (2002). Management of nitrogen fertigation of tomato with the use ${ }^{15} \mathrm{~N}$ technology. Results of a technical co-operation project on water balance and fertigation for crop improvement in West Asia. International Atomic Energy Agency (IAEA), Vienna, Austria, pp. 27 - 40. 


\section{تأثير مسافات التخطيط و التسميد مع الرى على محصول الفاصوليا ومكوناته تحت نظام الرى بالغمر}

حامد حسن حامد - سيا محمود (حمد

$$
\text { معهد بحوث البساتين - مركز البحوث الزراعية ـ- القاهرة - مصر }
$$

أجريت هذه الدر اسة فى موسمين زر اعيين بمزرعة بحوث الخضر بمدينة قها- محافظة القليوبية خلال عامى

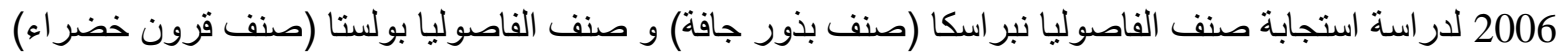

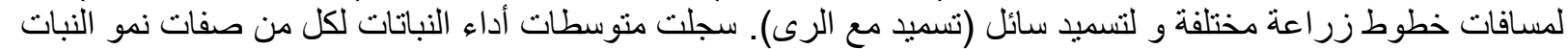

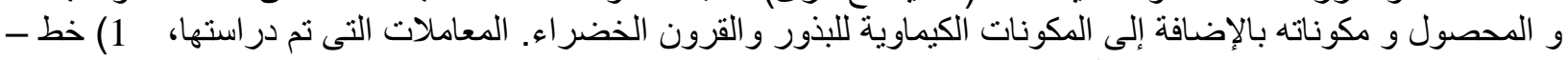

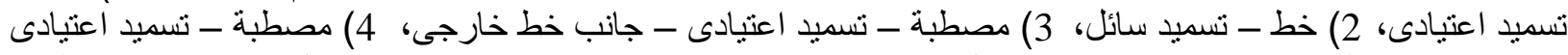

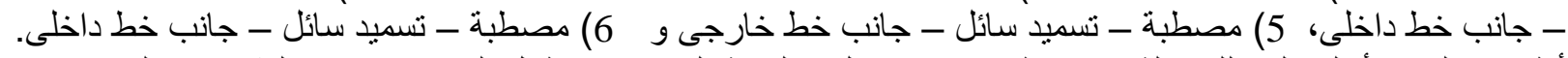

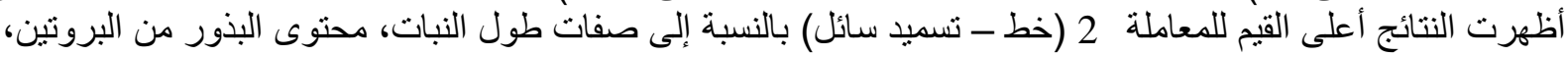

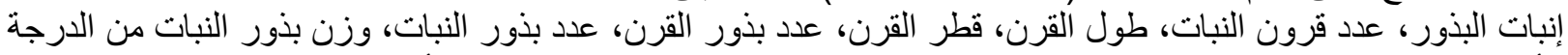

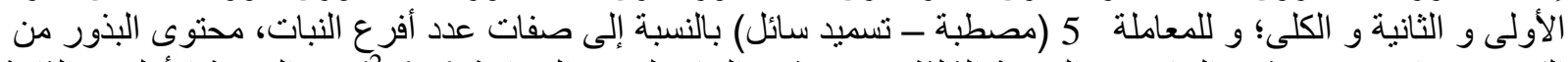

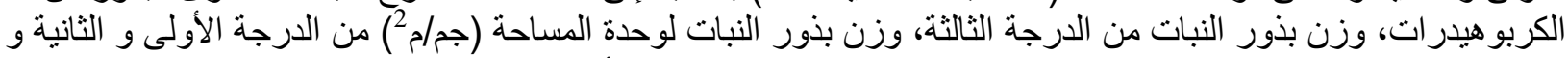

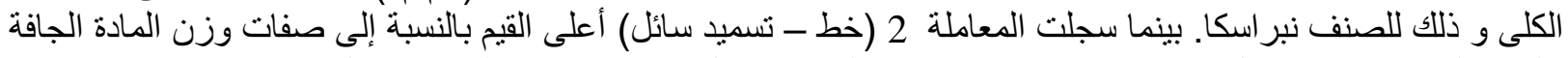

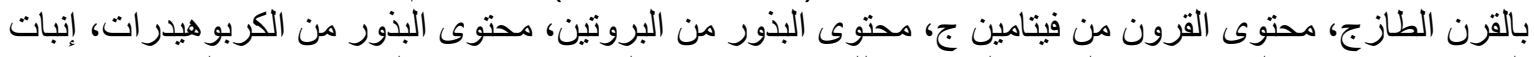

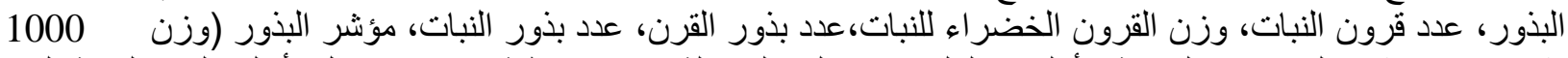

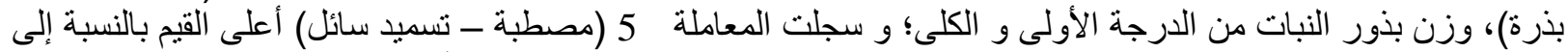

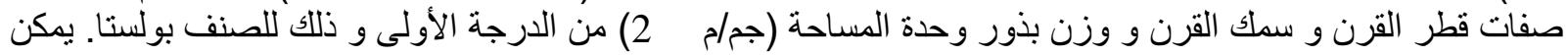

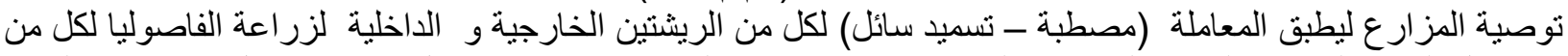

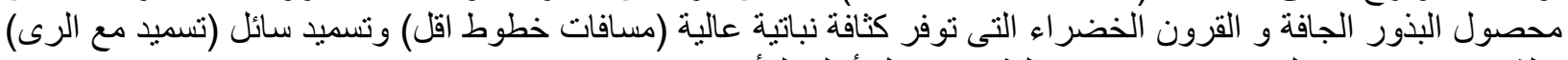

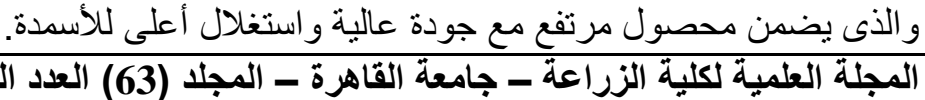

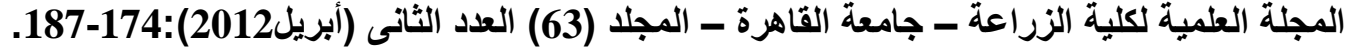

